Distribution Categors:

LMFBR Reactor Plant

Systems (UC-79i)

ANI. $79-27$

ARGONNE NATIONAL LABORATORY

9700 South Cass Averiue

Argonne, Illinois 60439

FISSION-PRODUCT RELEASES

TO THE PRIMARY SYSTEM OF EBR-II

FROM APRIL 1977 TO MAY 1978

by

B. Y. C. So, K. C. Gross, J. D. B. Lambert,

F. S. Kirn,* E. R. Ebersole,* and M. T. Laug*

EBR-II Project

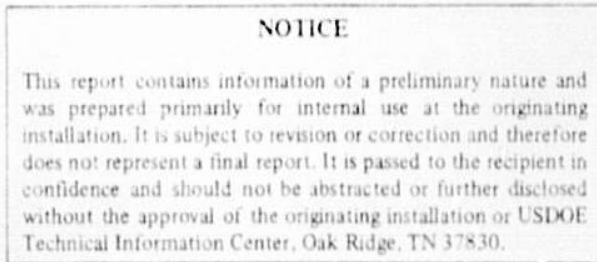

July 1979

-Argonne-West 


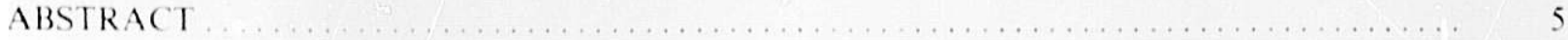

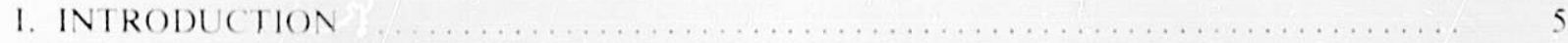

II. METHODS TO MONITOR ANDIDENTIFY FISSION-PRODUCT SOURCES ........ 5

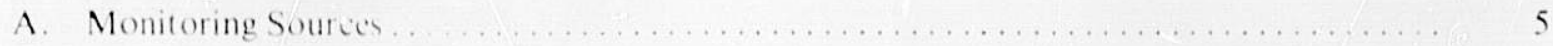

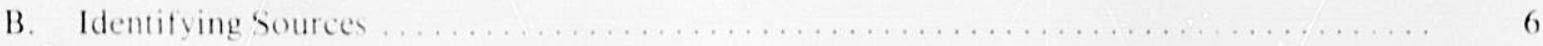

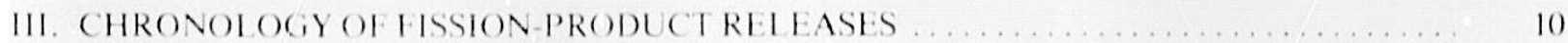

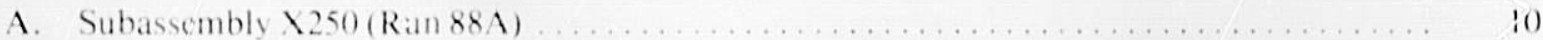

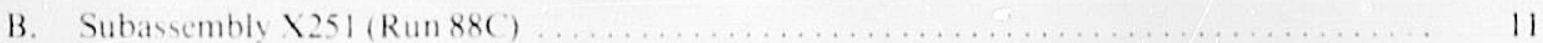

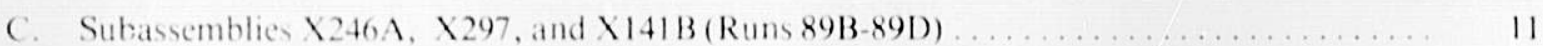

D. Subassemblies $\times 298, \times 1811$, and $\times 203$ D) (Runs 90 B-90D) $\ldots \ldots \ldots \ldots \ldots \ldots$

L. Subasemblics $\times 214, \times 282, \times 294, \times 235 \mathrm{~A}$, and $\times 291$ (Rans 91 and 92 ) ........... 16

1. Subassemblies $\times 206 \mathrm{~A}, \times 154 \mathrm{~A}, \times 271 \mathrm{~A}, \times 342, \times 203 \mathrm{D}$, and $\mathrm{C}-2884 \mathrm{~A}$

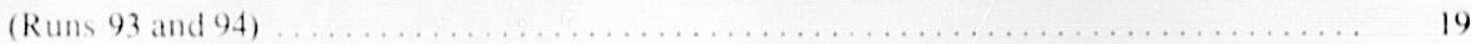

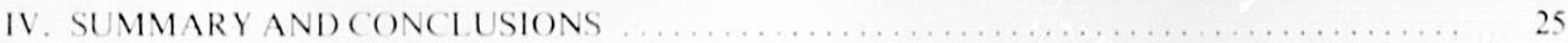

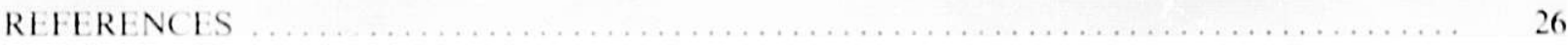


IIST OF FIGLRES

No.

Title

Page

1. Measured ${ }^{134} \mathrm{Xe}{ }^{129} \mathrm{Xe}$ Ration in Mark-11 and Mixed-oxide Fuel Elements as a

Function of Burnup

2. Two-dimensional Xenon-lag Map tor Rums 92 and $93 \ldots \ldots \ldots \ldots \ldots \ldots$

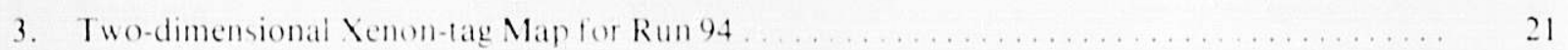

\section{IST OF TABLES}

No.

Title

Page

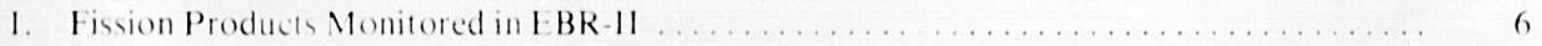

11. Methods Used to Identify Sources of Fission-product Releases in EBR-II . . . . . . . . 7

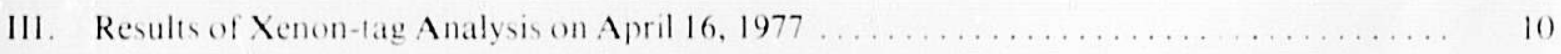

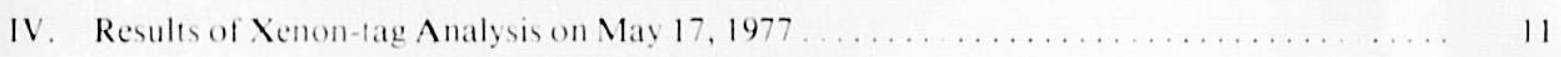

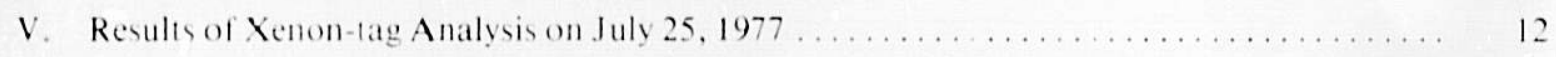

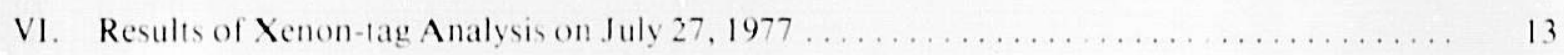

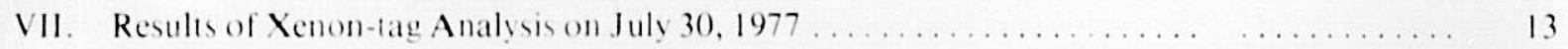

VIII. Results of Xenon-1ag Analysis on August $31,1977 \ldots \ldots \ldots \ldots \ldots \ldots$

IX. Results of Xenon-lag Analysis on September $7,1977 \ldots \ldots \ldots \ldots \ldots \ldots$

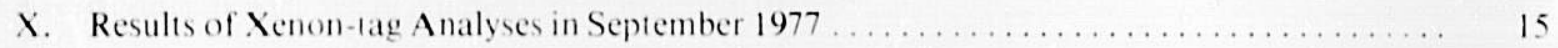

XI. Results of Xenon-iag Analyses on October 12 and $14,1977 \ldots \ldots \ldots \ldots$

XII. Results of Xenon-tag Analysis on October $21,1977 \ldots \ldots \ldots \ldots \ldots$

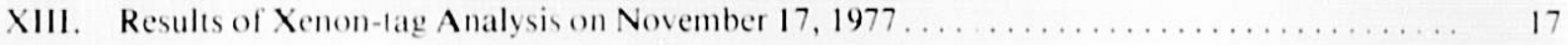

XIV. Results of Xenon-lag Analysis on December 14, $1977 \ldots \ldots \ldots \ldots \ldots$

XV. Results of Xenon-1ag Analysis on December $22,1977 \ldots \ldots \ldots \ldots \ldots$

XVI. Summary of Elements Breached in Runs 91 and $92 \ldots \ldots \ldots \ldots \ldots$

XVII. Results of Xenon-lag Analyses in January-March $1978 \ldots \ldots \ldots \ldots \ldots$

XVIII. Summary of Primary Suspects for April 15 and 16, 1978, Fission-product Releases ....... 20

XIX. Results of Xenon-lag Analyses in March-May $1978 \ldots \ldots \ldots \ldots \ldots 2$

XX. Suspect Subassemblies with ${ }^{129} \mathrm{Xe} /{ }^{128} \mathrm{Xe}$ Tag Ratios Greater than $5.97 \ldots \ldots \ldots$

XXI. Summary of Elements Breached in Runs 93 and $94 \ldots \ldots \ldots \ldots \ldots$ 


\title{
FISSION-PRODUCT RELEASES TO THE PRIMARY SYSTEM OF EBR-\|I FROM APRIL 1977 TO MAY 1978
}

\author{
by \\ B. Y. C. So, K. C. Gross, J. D. B. Lamberl, \\ F. S. Kirn, E. R. Ebersole, and M. T. Laug
}

\begin{abstract}
Suspected fission-product releases from 18 subassemblies between April 1977 and May 1978 are described. Postirradiation examinations on 15 of the suspect subassemblies confirmed that all contained one or more breached elements. Except for two untagged subassemblies, xenon tagging was the primary method of identification, although other methods were used where appropriate. Methods to monitor and identify fission-product sources are discussed. Problems encountered with multiple-element breaches are described. Overall, the effects of breached elements on plant availability were minimal during this reporting period. From all evidence, cladding breaching on elements in EBR-ll continues to be a benien process.
\end{abstract}

\section{INTRODUCTION}

Experimental fuei elements have been irradiated in EBR-11 since 1965. Cladding breaches have developed in a small fraction of these elements to cause release of fission products to the primary system of the reactor. Although several early releases of fission products were due to defects such as those found in closure welds, most have been from elements intentionally left in the reactor until breach of cladding.

The searches made for elements with breached cladding from 1967 to March 1977 are described in Refs. 1-10. The present report summarizes such operations from April 1977 to May 1978. During this period, cladding breaches developed in the unencapsulated elements of 17 experimental subassemblies and of one driver-fuel subassembly. Of the 18 subassemblies, eight contained mixed-oxide fuel, one contained advanced mixed-oxide fuel, four contained arbide or nitride fuel, and five contained metal fuel. One metal-fuel subassembly and two mixed-oxide subassemblies have not been examined in the Hot Fuel Examination Facility (HFEF) to confirm the pre ence of breached elements.

This report summarizes methods to monitor and identify sources of fission-product releases, describes the releases in chronological order, and discusses (1) experience gained from identifying the sources and (2) the impact of the releases on EBR-II operations.

\section{METHOIS TO MONITOR AND IDENTIFY FISSION-PRODUCT SOURCES}

\section{A. Monitoring Sources}

The fission products released from an element with breached cladding in EBR-II are monitored in several ways. The activities of selected fission-gas isotopes are measured qualitatively by the fission-gas monitor (FGM), ${ }^{5}$ the reactor cover-gas monitor (RCGM), ${ }^{11}$ and the germanium-lithium argon-scanning system (GLASS). ${ }^{12}$ These monitors use a common supply of argon cover gas, which is extracted from the T nozzie of 
the reactor. The gas is aged about $2 \mathrm{~min}$ to suppress the 38 -s activity of ${ }^{23} \mathrm{Ne}$. Periodically, $10-\mathrm{mL}$ grab samples of cover gas are obtained from the same nozzle and counted in the laboratory to directly measure the activities of ${ }^{133} \mathrm{Xe}$ and ${ }^{135} \mathrm{Xe}$. At the time of a release, a tag sample of about $15 \mathrm{ft}^{3}\left(0.42 \mathrm{~m}^{3}\right)$ of cover gas is also treated cryogenically to concentrate isoiopes of xenon for mass spectrometry; the presence of ${ }^{124} \mathrm{Xe}$ and ${ }^{126} \mathrm{Xe}$ in these samples indicates that the release is from an element containing a xenon tag. Any delayed neutrons released from the source are detected in a bypass flow of the primary sodium by the fuel-elementrupture-detector (FERD) system. ${ }^{5}$ Finally, samples of sodium taken from the primary tank are analyzed for the presence of ${ }^{131} \mathrm{I},{ }^{137} \mathrm{Cs},{ }^{235} \mathrm{U}$, and ${ }^{239} \mathrm{Pu} .{ }^{13}$ Plutonium has never been detected in the primary sodium.

During normal operation, fairly reproducible background fission-product activities caused by fissioning of a small quantity of "tramp" uranium in the core are observed in the sodium and cover gas. The uranium is thought to be present as a contaminant on or near the surfaces of stainless steel components.

Table I summarizes the fission-product activities routinely monitored in EBR-II and their normal background-activity levels when no sources other than tramp uranium are in the reactor.

TABLE I. Fission Products Monitored in EBR-II

\begin{tabular}{lcccc}
\hline Isotope & Half-life & $\begin{array}{c}\text { Decay Constant, } \\
\mathrm{s}^{-1}\end{array}$ & $\begin{array}{c}\text { Monitoring } \\
\text { System }\end{array}$ & $\begin{array}{c}\text { Normal Background } \\
\text { Activity at } 62.5 \mathrm{MWl}, \mu \mathrm{Ci} / \mathrm{mL}^{\mathrm{a}}\end{array}$ \\
\hline${ }^{85 \mathrm{~m}} \mathrm{Kr}$ & $4.4 \mathrm{~h}$ & $4.38 \times 10^{-5}$ & GL ASS, RCGM & $3.4 \times 10^{-4} \mathrm{~b}$ \\
${ }^{87} \mathrm{Kr}$ & $76.0 \mathrm{~min}$ & $1.52 \times 10^{-4}$ & GLASS & $1.5 \times 10^{-4} \mathrm{~b}$ \\
${ }^{88} \mathrm{Kr}$ & $2.79 \mathrm{~h}$ & $6.90 \times 10^{-5}$ & GLASS, FGM & $5.6 \times 10^{-4} \mathrm{~b}$ \\
${ }^{89} \mathrm{Kr}$ & $3.18 \mathrm{~min}$ & $3.63 \times 10^{-3}$ & FGM & \\
${ }^{133} \mathrm{Xe}$ & $5.27 \mathrm{~d}$ & $1.52 \times 10^{-6}$ & GLASS, RCGM, & $1.5 \times 10^{-3} \mathrm{C}$ \\
${ }^{135 \mathrm{~m}} \mathrm{Xe}$ & $15.7 \mathrm{~min}$ & $7.36 \times 10^{-4}$ & Grgon grab sample & $2.3 \times 10^{-5} \mathrm{~b}$ \\
${ }^{135} \mathrm{Xe}$ & $9.16 \mathrm{~h}$ & $2.10 \times 10^{-5}$ & GLASS, RCGM & $2.5 \times 10^{-3} \mathrm{c}$ \\
${ }^{138} \mathrm{Xe}$ & $14.2 \mathrm{~min}$ & $8.13 \times 10^{-4}$ & GLASS, FGM & $7.5 \times 10^{-5} \mathrm{~b}$ \\
${ }^{131} \mathrm{I}$ & $8.07 \mathrm{~d}$ & $9.95 \times 10^{-7}$ & Sodium sample & $4.0 \times 10^{-5} \mu \mathrm{Ci} / \mathrm{gc}^{\mathrm{C}}$ \\
${ }^{137} \mathrm{Cs}$ & $30.1 \mathrm{yr}$ & $7.30 \times 10^{-10}$ & Sodium sample & $6.5 \times 10^{-2} \mathrm{c}, \mathrm{d}$ \\
\hline
\end{tabular}

a $_{\mu} \mathrm{Ci}=37 \mathrm{kBq}$.

b Based on GLASS data.

${ }^{\mathrm{C}}$ Based on laboratory analyses of argon or sodium samples.

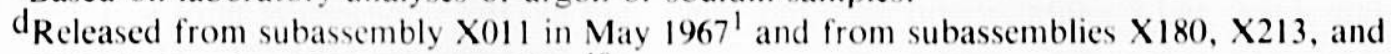
X194 in October 1974-January 1975. ${ }^{10}$

\section{B. Identifying Sources}

Twelve methods have been developed over the years to help identify fission-product sources in EBR-II. Table II summarizes how each method is used during a release to identify the source of the release. No method is used exclusively; if one method strongly indicates a particular subassembly as a source, the other methods are applied to that subassembly. If diagnosis is then inconclusive, the search continues. Fortunately, the use of xenon tagging has reduced such iteration to a minimum. ${ }^{8 \cdot 10}$

The first method, based on cladding-failure statistics, relies solely on previous experience and is used when several cladding breaches have already occurred in a large group of similar elements such as the driver-fuel elements of EBR-11.14-15 The method is applied with somew hat less certainty to predict the likelihood of cladding failure in similar groups of experimental elements. ${ }^{16}$ 
TABI.E. II. Methods Used to Identify Sources of Fission-product Releases in EBR-II

\begin{tabular}{|c|c|c|c|c|c|}
\hline & Method & Data Source & Purpose & Advantages & Disadvantages \\
\hline 1. & Weibull failure & $\begin{array}{l}\text { a. Previous failures } \\
\text { b. Surveillance }\end{array}$ & $\begin{array}{l}\text { Ranks suspects } \\
\text { by failure } \\
\text { probability }\end{array}$ & $\begin{array}{l}\text { Predicts breach in ad- } \\
\text { vance; helps rank other- } \\
\text { wise equal suspects }\end{array}$ & $\begin{array}{l}\text { Assumes common } \\
\text { mode of failure; } \\
\text { limited by previous } \\
\text { experience }\end{array}$ \\
\hline & $\begin{array}{l}{ }^{135 \mathrm{~m}} \mathrm{Xe} \\
\text { behavior }\end{array}$ & GL ASS activity & $\begin{array}{l}\text { Indicates release } \\
\text { of bond sodium }\end{array}$ & Rapid & $\begin{array}{l}\text { None; occasionally } \\
\text { overlooked }\end{array}$ \\
\hline & $\begin{array}{l}\text { Normalized } \\
\text { excursion } \\
\text { parameter }\end{array}$ & G: ASS activity & $\begin{array}{l}\text { Discriminates } \\
\text { between metal } \\
\text { and oxide }\end{array}$ & Rapid & $\begin{array}{l}\text { Empirical; uses com- } \\
\text { plex release char- } \\
\text { acteristics that may } \\
\text { give ambiguous } \\
\text { results }\end{array}$ \\
\hline & $\begin{array}{l}\text { Ratio } \\
{ }^{131} \mathrm{Xe} /{ }^{134} \mathrm{Xe}\end{array}$ & Tag sample & $\begin{array}{l}\text { Discriminates } \\
\text { between metal } \\
\text { and oxide }\end{array}$ & $\begin{array}{l}\text { Uses abundant stable } \\
\text { isotopes of xenon }\end{array}$ & $\begin{array}{l}\text { Can be affected by } \\
\text { tag in low-burnup } \\
\text { elements }\end{array}$ \\
\hline & $\begin{array}{l}\text { Ratio } \\
{ }^{134} \mathrm{Xe} /{ }^{133} \mathrm{Xe}\end{array}$ & $\begin{array}{l}\text { a. Tag sample } \\
\text { b. Power history }\end{array}$ & $\begin{array}{l}\text { Discriminates } \\
\text { between metal } \\
\text { and oxide }\end{array}$ & $\begin{array}{l}\text { Identifies type and } \\
\text { burnup of suspect }\end{array}$ & $\begin{array}{l}\text { Ratio changes for } \\
\text { same element; af- } \\
\text { fected by fuel and } \\
\text { breach geometry }\end{array}$ \\
\hline & $\begin{array}{l}\text { Ratio } \\
{ }^{134} \mathrm{Xe} /{ }^{12 \pi} \mathrm{Xe}\end{array}$ & Tag sample & $\begin{array}{l}\text { Determines } \\
\text { burnup level of } \\
\text { untagged element }\end{array}$ & $\begin{array}{l}\text { Eliminates suspect with } \\
\text { too high or low burnup }\end{array}$ & $\begin{array}{l}\text { For small release, } \\
\text { natural background } \\
\text { contamination can be } \\
\text { significant }\end{array}$ \\
\hline 7. & $\begin{array}{l}\text { Fission-gas } \\
\text { volume }\end{array}$ & $\begin{array}{l}\text { a. Grab sample } \\
\text { b. Tag sample }\end{array}$ & $\begin{array}{l}\text { Identifies sus- } \\
\text { pects by gas } \\
\text { release }\end{array}$ & $\begin{array}{l}\text { Eliminates low-burnup } \\
\text { suspects }\end{array}$ & $\begin{array}{l}\text { Usually limited } \\
\text { applicabilities }\end{array}$ \\
\hline 8. & Xenon tag & $\begin{array}{l}\text { a. Grab sample } \\
\text { b. Tag sample } \\
\text { c. Surveillance }\end{array}$ & $\begin{array}{l}\text { Identifies sus- } \\
\text { pects by tag } \\
\text { composition }\end{array}$ & $\begin{array}{l}\text { Limits choice to one to } \\
\text { three suspects }\end{array}$ & $\begin{array}{l}\text { Exposure changes in } \\
\text { tag; sometimes small } \\
\text { tag releases; } \\
\text { contamination }\end{array}$ \\
\hline & $\begin{array}{l}\text { Fission-gas } \\
\text { and tag } \\
\text { volumes }\end{array}$ & $\begin{array}{l}\text { a. Grab sample } \\
\text { b. Tag sample } \\
\text { c. Surveillance }\end{array}$ & $\begin{array}{l}\text { Discriminates } \\
\text { between suspects } \\
\text { with similar tag } \\
\text { compositions }\end{array}$ & Ranks xenon-tag suspects & $\begin{array}{l}\text { As above; also, early } \\
\text { tag volumes were } \\
\text { variable }\end{array}$ \\
\hline 10. & $\begin{array}{l}\text { Lift-and-hold } \\
\text { test }\end{array}$ & GLASS activity & $\begin{array}{l}\text { Identifies sus- } \\
\text { pects by gas } \\
\text { release }\end{array}$ & $\begin{array}{l}\text { Confirms suspected } \\
\text { subassembly }\end{array}$ & $\begin{array}{l}\text { Reactor shutdown re- } \\
\text { quired; only positive } \\
\text { response meaningful; } \\
\text { time-consuming }\end{array}$ \\
\hline 11. & $\begin{array}{l}\text { FUM isolation } \\
\text { test }\end{array}$ & GLASS activity & $\begin{array}{l}\text { Iden ifies sus- } \\
\text { pects by gas } \\
\text { release }\end{array}$ & $\begin{array}{l}\text { Confirms suspected sub- } \\
\text { assembly; can be } \\
\text { conducted at reactor } \\
\text { operator's convenience; } \\
\text { minimizes interference } \\
\text { from cover-gas activity }\end{array}$ & $\begin{array}{l}\text { Only positive re- } \\
\text { sponse meaningful; } \\
\text { can tolerate only low } \\
\text { decay heat }\end{array}$ \\
\hline 12. & $\begin{array}{l}\text { Flux-tilting } \\
\text { test }\end{array}$ & FERD activity & $\begin{array}{l}\text { Narrows down } \\
\text { suspects to a sec- } \\
\text { tion of the core }\end{array}$ & Easy to perform & $\begin{array}{l}\text { Suspect must be } \\
\text { delayed-neutron emit- } \\
\text { ter and located adja- } \\
\text { cent to control rod; } \\
\text { only positive and } \\
\text { reproducible response } \\
\text { is meaningful }\end{array}$ \\
\hline
\end{tabular}


The next two methods ( 2 and 3 in Table II) use the raw activity data obtained during a release. If the activity of ${ }^{135 \mathrm{~m}} \mathrm{Xe}$ increases while the ${ }^{138} \mathrm{Xe}$ activity stays at background level, or if the decay of ${ }^{135 \mathrm{~m}} \mathrm{Xe}$ is much slower than that of ${ }^{138} \mathrm{Xe}$ after the initial release, the source is likely to be a sodium-bonded element that is losing some of its bond, and indine, to the primary coolant. Similarly, if the initial release contains significant amounts of short-lived gas isotopes and the ${ }^{135} \mathrm{Xe}$ decays alorig with ${ }^{138} \mathrm{Xe}$, the source of the release is more likely to be a gas-bonded element than a sodium-bonded element. ${ }^{9-10}$ Although rapid, both methods are used with caution, because extraneous factors can easily affect the measured activity of short-lived radioisotopes.

The six methods (4-9) that involve mass spectrometry of samples of cover gas are lengthy, but generally lead to an accurate diagnosis. Two of them (4 and 5 ) help identify the type of source by measured ratios of the xenon isotopes. The ratio of stable ${ }^{131} \mathrm{Xe}$ to stable ${ }^{134} \mathrm{Xe}$ (method 4 ) has been found to be consistently lower for uranium fuels than for fuels containing both uranium and plutonium. ${ }^{17}$ Similarly, the ratio of stable ${ }^{134} \mathrm{Xe}$ to radioactive ${ }^{133} \mathrm{Xe}(\operatorname{method} 5$ ) increases with burnup in a different manner for the two types of fuel. $^{18}$

Method 6 determines the burnup level of untagged fuel elements. This method is based on determining the ratio ${ }^{134} \mathrm{Xe} / 128 \mathrm{Xe}$. This ratio was etosen because the largest percentage of stable xenon fission products is ${ }^{134} \mathrm{Xe}$, which is mainly produced through the decay chain

$$
{ }^{134} \mathrm{Te} \stackrel{42 \mathrm{~min}}{\longrightarrow} 134 \mathrm{I} \stackrel{52.6 \mathrm{~min}}{\longrightarrow}{ }^{134} \mathrm{Xe} \text { (stable) }
$$
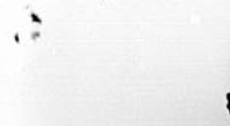

and the ${ }^{128} \mathrm{Xe}$ is produced through the ${ }^{127} \mathrm{I}(\mathrm{n}, \gamma)$ reaction to ${ }^{128} \mathrm{I}$ and the subsequent $\beta$ decay. The ratio should, change substantially from initial to midlife irradiation and from midlife and to end-of-life irradiation.

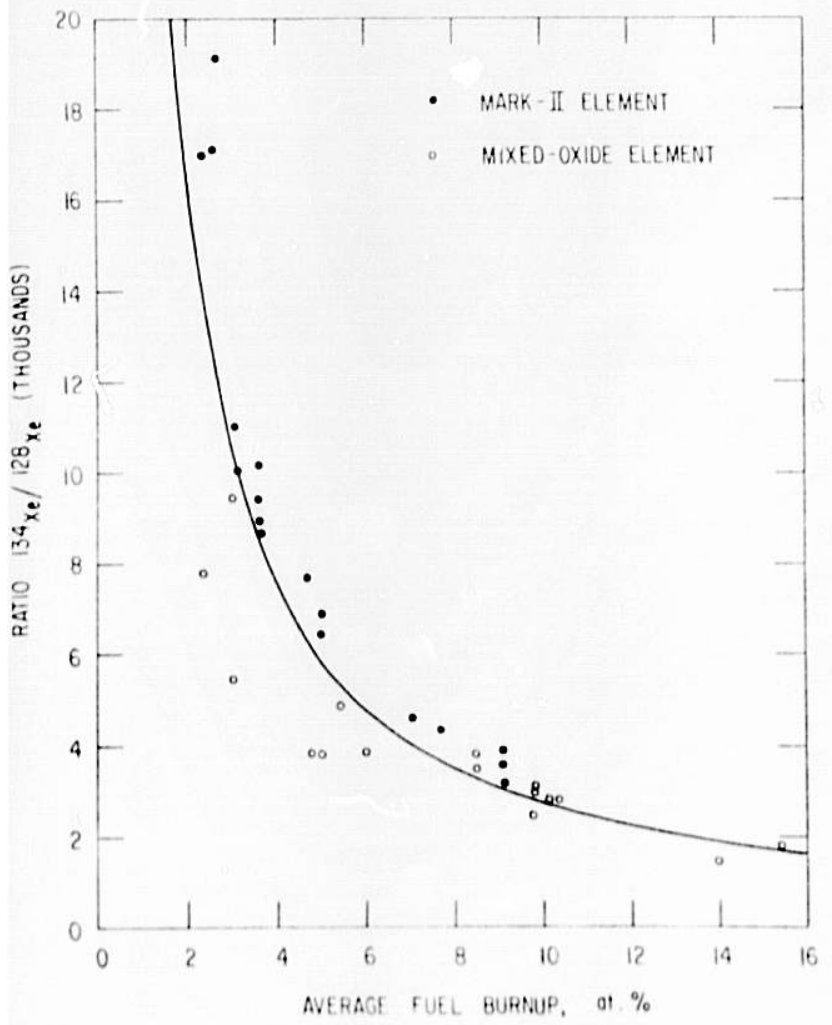

Fig. 1. Measured ${ }^{134} \mathrm{Xe}^{12 k} \mathrm{Xe}$ Ratios in Mark-11 and Mixedoxide Fuel Elements as a Function of Burnup. ANI Neg. No. 104.78.48 Rev.
Figure 1 shows the ${ }^{134} \mathrm{Xe} /{ }^{128} \mathrm{Xe}$ ratios in Mark-II (metal-driver-fue!) and mixed-oxide elements as a function of average burnup. The data were. obtained from plenum-puncture tests of untagged fuel elements irradiated in EBR-II.

Method 7 compares the measured volume of fission gas released from a source with the calculated volumes of fission gas in the plenums of all elements in the core. In this way, elements having less fission gas in their plenums than the volume of fission gas released can be eliminated as suspects. The calculated plenum contents are based on empirical correlations of fission-gas release $\mathrm{e}^{19-20}$ and are updated for each EBR-II run.

The next two quantitative methods ( 8 and 9$)$, which involve recognition of a xenon lag, are the most accurate and, because all experimental EBR-II elements are now tagged, are also the most frequently used. A xenon tag is about a $1-\mathrm{mL}$ volume of a mixture of ${ }^{124} \mathrm{Xe},{ }^{126} \mathrm{Xe},{ }^{128} \mathrm{Xe}$, and ${ }^{129} \mathrm{Xe}$ that is added to an element during fabrication. The elements in each subassembly contain the same unique tag. Method 8 simply matches the measured tag composition in the cover gas to the closest tag composition known to be in the reactor. This comparison must allow for the composition changes that occur because of ${ }^{124} \mathrm{Xe}$ burnout and ${ }^{128} \mathrm{Xe}$ 
production during irradiation. ${ }^{21}$ Method 9 discriminates between tags of similar composition by comparing the measured volume ratio of fission gas to tag gas in the cover gas with the calculated volume ratios for the elements in the suspect subassemblies.22 Again, the calculated ratios are obtained from the known amounts of tag and the estimated accumulation of fission gas in the elements.

The lift-and-hold test and the FUM isolation iest (methods 10 and 11) are usually used only for confirming that a suspect subassembly is indeed the source of fission-gas release. The lift-and-hold test is performed with the reactor shut down. Suspect subassemblies are lifted out of the core one at a time and held at the elevated position for a period of time. The lowering of the sodium head in the subassembly may induce a bubble release from the breached element.

The FUM isolation test is limited to subassemblies with low decay heat, which means that the subassemblies under test usually will have been in the storage basket for a number of days before the test. During the test, the suspect subassembly is lifted out of the storage basket and held in the cover gas by the gripper of the fuelunloading machine (FUM). Argon is used to blow the residual sodium out of the subassembly. Then the subassembly is isolated in the FUM for a period of time to see if fission gas is released. The elimination of the sodium head in the subassembly may induce fission-gas release from the breached element. Isolation in the FUM also helps to minimize the opportunity for contamination from the cover gas interfering with the test and increases the sensitivity of detecting a small release from the breached element.

A flux-tilting test (method 12) consists of performing a simple banking of control rods, which either increases or decreases the flux adjacent to the banked rods by $-2-3 \%$. The resultant temperature change in the subassembly may increase or decrease the delayed-neutron emission rate from the breached element. 


\section{CHRONOLOGY OF FISSION-PRODUCT RELEASES}

\section{A. Subassembly X250 (Run 88A)}

After the annual shutdown for maintenance, the reactor reached $62.5 \mathrm{MWt}$ on April 8, 1977, with the first of a series of $\mathrm{UO}_{2}$ diagnostic tests (X301) in the core. (These tests were performed to determine the response of the fission-product-monitoring systems of EBR-II. ${ }^{23}$ ) Shortly after startup, the fission products released from the predefected $\mathrm{UO}_{2}$ element in subassembly X301 had increased the ${ }^{135 m} \mathrm{Xe},{ }^{135} \mathrm{Xe},{ }^{133} \mathrm{Xe}$, and ${ }^{85 m} \mathrm{Xe}$ activities in the cover gas to above their normal backgrounds from "tramp" uranium. By April 13, pseudoequilibrium activity levels were established for isotopes monitored by the GLASS. On April 14, sharp increases of activity levels suggested the likelihood of the presence of a second fission-product source.

Table III summarizes the results of the analysis of a xenon-tag sample taken on April 16 . The ${ }^{131} \mathrm{Xe} /{ }^{134} \mathrm{Xe}$ ratio of 0.417 indicated that the second source of the fission gas was a Mark-II element. Although none of the subassemblies matched the measured tag composition well, only subassembly X250 contained a tag with a composition similar to that of the tag sample. Thus, only this subassembly, which had a peak burnup of 10.6 at. \%, was removed from the core. The absence of abnormal cover-gas activity upon the subsequent startup confirmed that subassembly $\mathrm{X} 250$ was the second source for the additional fission-gas release during April 14-16.

TABLE III. Results of Xenon-tag Analysis on April 16, 1977

\begin{tabular}{|c|c|c|}
\hline & $\begin{array}{l}\text { Determined } \\
\text { from } \\
\text { Cover-gas } \\
\text { Sample }\end{array}$ & $\begin{array}{l}\text { Predicted for } \mathrm{X} 250 \text { at } \\
\text { Peak Burnup of } 10.6 \text { at. } \%\end{array}$ \\
\hline Xenon volume, $\mathrm{mL}$ & 23.4 & - \\
\hline Tag volume, $\mathrm{mL}$ & 0.36 & - \\
\hline $\mathrm{FG} / \mathrm{TG}$ ratio & 75 & $60-86$ \\
\hline $\begin{array}{l}\text { Volume of gas in } \\
\text { element plenum, } \mathrm{mL}\end{array}$ & $74-106$ & 84 \\
\hline \multicolumn{3}{|l|}{ Xenon isotopic ratios } \\
\hline $131 / 134$ & 0.417 & $\leq 0.426$ \\
\hline $134 / 133$ & 1618 & - \\
\hline $129 / 128$ & 3.6 & 5.60 \\
\hline $129 / 124$ & 65.95 & 63.95 \\
\hline $128 / 124$ & 18.33 & 11.41 \\
\hline $126 / 124$ & 0.603 & 0.545 \\
\hline $129 / 126$ & 109.5 & 117.4 \\
\hline
\end{tabular}

"Ratio of total volume of stable fission gas (FG) to volume of tag gas (TG) as loaded.

Postirradiation examination indicated that element 91 from subassembly X250 had the largest weight loss of all elements in the subassembly. Gamma scanning showed that the weight loss was not caused by loss of sodium bond. Therefore, the breach site had to be in the plenum region of the element. Visual examination showed the possible breach site to be in an area of mechanical deformation at the top of the plenum region. 
The deformation had been caused by handling the element outside the reactor. The weight loss was about $40 \%$ of the calculated weight of the fission-gas inventory in the plenum.

\section{B. Subassembly X251 (Run 88C)}

The reactor reached $62.5 \mathrm{MWt}$ on May 7, 1977, with the second $\mathrm{UO}_{2}$ diagnostic test $(\mathrm{X} 302)$ in the core. Because of the release of fission products from the predefected $\mathrm{UO}_{2}$ element in subassembly $\mathrm{X} 302$, both the delayed-neutron signals and the cover-gas activities were above normal background.

On May 16, the reactor power was reduced to $50 \mathrm{MW}$ for $6 \mathrm{~h}$ to repair a steam leak in the power plant. Upon the return to full power, all cover-gas activities surged above their pseudoequilibrium levels before the power reduction. Analysis of a tag sample taken on May 17 identified Mark-1I subassembly X251 as the source of the second fission-product release. The peak burnup of that subassembly was 9.9 at. \% . Table IV summarizes the results of the tag analysis.

TABLE IV. Results of Xenon-tag Analysis on May 17, 1977

\begin{tabular}{lcc}
\hline & $\begin{array}{c}\text { Determined } \\
\text { from } \\
\text { Cover-gas } \\
\text { Sample }\end{array}$ & $\begin{array}{c}\text { Predicted for X251 at } \\
\text { Peak Burnup of } 9.9 \text { at. \% }\end{array}$ \\
\hline Xenon volume, $\mathrm{mL}$ & 4.5 & - \\
Tag volume, $\mathrm{mL}$ & 0.053 & - \\
FG/TG ratio & & $60-77$ \\
Volume of gas in & 98 & 79 \\
element plenum, mL & $101-129$ & \\
Xenon isotopic ratios & & - \\
$131 / 134$ & 0.424 & 3.427 \\
$134 / 133$ & 548 & 31.13 \\
$129 / 128$ & 3.32 & 9.67 \\
$129 / 124$ & 37.54 & 0.507 \\
$128 / 124$ & 11.30 & 61.39 \\
$126 / 124$ & 0.519 & - \\
$129 / 126$ & 2.33 & \\
\hline
\end{tabular}

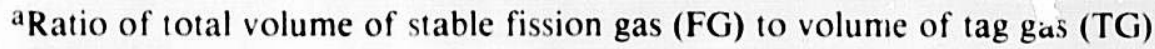
as loaded.

Postirradiation examınation identified a breach in element 24 at the dimple area. The ${ }^{135 \mathrm{~m} X e \text { activity of }}$ 9.3 times above normal background from the second $\mathrm{UO}_{2}$ diagnostic test might have masked a telitale indication of sodium release from subassembly $\mathrm{X} 251$ before release of plenum gas from it. Release of iodine with sodium increases the ${ }^{135 \mathrm{~m}} \mathrm{Xe}$ activity in the cover gas.

\section{Subassemblies X246A, X297, and X141B (Runs 89B-89D)}

The reactor reached $62.5 \mathrm{MWt}$ on May 21,1977 , with the second $\mathrm{UO}_{2}$ diagnostic test $(\mathrm{X} 302)$ in the core. Intermittent purges of the primary cover gas with the cover-gas cleanup system (CGCS) were used to keep the combined ${ }^{133} \mathrm{Xe}$ and ${ }^{135} \mathrm{Xe}$ activity below $1.2 \mu \mathrm{Ci} / \mathrm{mL}(44.4 \mathrm{kBq} / \mathrm{mL})$. On July 25 an increase of 
more than 200-fold in cover-gas activity indicated the presence of a second fission-product source. The recorded peak ${ }^{133}$ Xe activity from grab samples of cover gas was $6.7 \mu \mathrm{Ci} / \mathrm{mL}(247.9 \mathrm{kBq} / \mathrm{mL})$. Analysis of a xenon-tag sample taken on July 25 indicated that the high-burnup (9.5 peak at. $\%_{0}$ ) element in subassembly $\mathrm{X} 246 \mathrm{~A}$ was the source of the additional fission-product release.

Postirradiation examination identified the breached element as $\mathrm{k} 4-4$, a sodium-bonded and shrouded carbide-fuel element. (In a shrouded element, a shroud tube centers the fuel inside the cladding to minimize fuel-cladding mechanical interaction.) This was the first failure of a shrouded element. Table V summarizes the results of the xenon-tag analysis on July 25.

TABLE V. Results of Xenon-tag Analysis on July 25, 1977

\begin{tabular}{|c|c|c|}
\hline & $\begin{array}{l}\text { Determined } \\
\text { from } \\
\text { Cover-gas } \\
\text { Sample }\end{array}$ & $\begin{array}{l}\text { Predicted for X246A at } \\
\text { Peak Burnup of } 9.5 \text { at. } \sigma_{0}\end{array}$ \\
\hline Xenon volume, $\mathrm{mL}$ & 27.4 & - \\
\hline Tag volume, $\mathrm{mL}$. & 0.82 & - \\
\hline $\mathrm{FG} / \mathrm{TG}_{\text {ratio }}$ & 38 & 32 \\
\hline $\begin{array}{l}\text { Volume of gas in } \\
\text { element plenum, } \mathrm{mL}\end{array}$ & 59 & 49 \\
\hline \multicolumn{3}{|l|}{ Xenon isotopic ratios } \\
\hline $131 / 134$ & 0.452 & $\geq 0.428$ \\
\hline $134 / 133$ & 346 & - \\
\hline $129 / 128$ & 1.11 & 1.14 \\
\hline $129 / 124$ & 7.88 & 7.74 \\
\hline $128 / 124$ & 7.11 & 6.81 \\
\hline $126 / 124$ & 0.448 & 0.432 \\
\hline $129 / 126$ & 17.60 & 17.94 \\
\hline
\end{tabular}

"Ratio of total volume of stable fission gas (FG) to volume of tag gas (TG) as loaded.

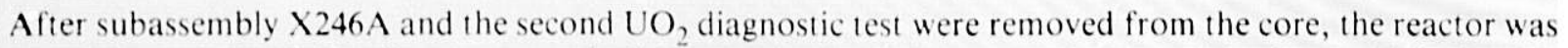
restarted on July 26. When the power reached $62.5 \mathrm{MWt}$, the above-normal "tramp" background fission-gas activities indicated the presence of a leaker. The ${ }^{133} \mathrm{Xe}$ activity peaked at $1.1 \mu \mathrm{Ci} / \mathrm{mL}(40.7 \mathrm{kBq} / \mathrm{mL}) \mathrm{on}$ July 27.

A xenon-tag sample was taken on July 27. The completely different tag composition confirmed that

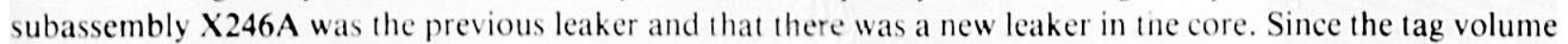
in the cover gas was only $0.025 \mathrm{~mL}$, substantial contamination from the X246A tag was expected. Table VI summarizes the results of the xenon-tag analysis on July 27 . Analysis with the MIXTAG code ${ }^{24}$ indicated that xenon tag from oxide subassembly $\times 297$, mixed with $46.68 \%$ xenon-tag contamination from subassembly $\times 246 \mathrm{~A}$, provided the best fit to the measured data. Because of the uncertainty in the analysis, and to ensure that the leaker would be removed, subassemblies X181E, X252, and X298, as well as X297, were removed from the core. Subassembly $\times 297$ was later identified as the leaker when it released fission gas while isolated in the FUM. It had a peak burnup of 10.4 at. \%. Postirradiation examination identified element 26 as the breached element in the subassembly. 
TABLE VI. Results of Xenon-tag Analysis on July 27, 1977

\begin{tabular}{|c|c|c|c|}
\hline & \multirow[b]{2}{*}{$\begin{array}{l}\text { Determined } \\
\text { from } \\
\text { Cover-gas } \\
\text { Sample }\end{array}$} & \multicolumn{2}{|c|}{ Predicted Values } \\
\hline & & $\begin{array}{l}\text { X297 at Peak } \\
\text { Burnup of } 10.4 \text { at. } \%\end{array}$ & $\begin{array}{c}\text { Assuming } 46.68 \% \text { of } \\
\text { Release from } \times 246 \AA^{\mathrm{a}} \text { and } \\
\text { Rest from X297 }\end{array}$ \\
\hline Xenon volume, $\mathrm{mL}$ & 1.93 & - & - \\
\hline Tag volume, $\mathrm{mL}$ & 0.025 & . & - \\
\hline $\mathrm{FG} / \mathrm{TG}$ rat:o ${ }^{\mathrm{b}}$ & 89 & 113 & - \\
\hline $\begin{array}{l}\text { Volume of gas in } \\
\text { element plenum, } \mathrm{mL}\end{array}$ & 98 & 124 & - \\
\hline \multicolumn{4}{|l|}{$\begin{array}{l}\text { Xenon isotopic } \\
\text { ratios }\end{array}$} \\
\hline $131 / 134$ & 0.448 & $\geq 0.422$ & $\geq 0.425$ \\
\hline $134 / 133$ & 92.5 & - & \\
\hline $129 / 128$ & 2.26 & 7.26 & 4.403 \\
\hline $129 / 124$ & 15.42 & 36.53 & 23.09 \\
\hline $128 / 124$ & 6.83 & 5.03 & 5.86 \\
\hline $126 / 124$ & 0.476 & 0.511 & 0.474 \\
\hline $129 / 126$ & 32.36 & 71.43 & 46.46 \\
\hline
\end{tabular}

apercentage for X246. A is based on July 25, 1977, xenon-tag composition in the cover gas.

${ }^{b}$ Ratio of total volume of stable fission gas (FG) to volume of tag gas (TG) as loaded.

The reactor reached $62.5 \mathrm{MWt}$ next on July 28 , and the core contained no leakers. On July 30 , however, a large increase of fission-gas activity indicated the presence of a fission-product source. The recorded peak ${ }^{133} \mathrm{Xe}$ activity from a grab sample of cover gas was $2.3 \mu \mathrm{Ci} / \mathrm{mL}(\mathrm{kBq} / \mathrm{mL})$. Xenon-tag analysis of a sample taken on July 30 identified oxide subassembly X141B as the source. Table VII summarizes the results of the xenon-tag analysis of July 30 . Postirradiation examination identified element 40 as the breached element in subassembly X141B.

TABLE VII. Results of Xenon-tag Analysis on July 30, 1977

\begin{tabular}{lcc} 
& $\begin{array}{c}\text { Determined } \\
\text { from } \\
\text { Cover-gas } \\
\text { Sample }\end{array}$ & $\begin{array}{c}\text { Predicted for X141 B at } \\
\text { Peak Burnup of } 6.8 \text { at. \% }\end{array}$ \\
\hline Xenon volume, $\mathrm{mL}$ & 48.83 & - \\
Tag volume, $\mathrm{mL}$ & 0.67 & - \\
FG/TG ratio & 84 & - \\
Volume of gas in & 59 & - \\
element plenum, mL & & \\
Xenon isotopic ratios & 0.447 & - \\
$131 / 134$ & 96.16 & 6.56 \\
$134 / 133$ & 6.46 & 17.85 \\
$129 / 128$ & 17.98 & 2.72 \\
$129 / 124$ & 2.78 & 0.388 \\
$128 / 124$ & 0.418 & 46.04 \\
$126 / 124$ & 43.03 & \\
$129 / 126$ & & \\
\hline
\end{tabular}

a Ratio of total volume of stable fission gas (FG) to volume of tag gas (TG) as loaded. 


\section{Subassemblies X298, X181E, and X203I) (Runs 90B and 90I)}

EBR-1I reached 62.5 MWt on August 19, 1977, with no leakers in the core. On August 31 , a large increase in cover-gas activity signified the presence of another fission-product source. The recorded peak ${ }^{133} \mathrm{Xe}$ activity from a grab sample of cover gas was $3.4 \mathrm{nCi} / \mathrm{mL}(125.8 \mathrm{~Bq} / \mathrm{mL}$ ). Analysis of a xenon-tag sample taken on August 31 identified oxide subassembly $\times 298$ (11.3 at. $\%$ peak burnup) as the source of the fission gas. Table VIII summarizes the results of the xenon-tag analysis. Postirradiation examiation identified element 29 as the breached element in subassembly $\times 298$.

TABIE VIII. Results of Xenon-1ag Analysis on August 31, 1977

\begin{tabular}{|c|c|c|}
\hline & $\begin{array}{l}\text { Determined } \\
\text { from } \\
\text { Cover-gas }\end{array}$ & Peak Burnup of 11.3 at. $\sigma_{0}$ \\
\hline Xenon volume, mL & 9.87 & - \\
\hline Tag volume, $\mathrm{ml}$ & 0.08 & - \\
\hline $\mathrm{FG} / \mathrm{TG}$ ratio & 142 & 126 \\
\hline $\begin{array}{l}\text { Volume of gas in } \\
\text { element plenum, mL }\end{array}$ & 156 & 139 \\
\hline \multicolumn{3}{|l|}{ Xenon isotopic ratios } \\
\hline $131 / 134$ & 0.443 & $\geq 0.423$ \\
\hline $134 / 133$ & 127 & - \\
\hline $129 / 128$ & 6.53 & 6.78 \\
\hline $129 / 124$ & 37.42 & 37.08 \\
\hline $128 / 124$ & 5.73 & 5.47 \\
\hline $126 / 12 \%$ & 0.542 & 0.519 \\
\hline $129 / 126$ & 69.0 & 71.43 \\
\hline
\end{tabular}

"Ratio of total volume of stable gas (FG) to volume of tag gas (TG) as loaded.

The reactor was restarted and reached $62.5 \mathrm{MWt}$ on September 2. The absence of short-half-life fission-gas activities confirmed that subassembly $\times 298$ was responsible for the fission-product release in run $90 \mathrm{~B}$.

Another fission-gas release became apparent on September 5. The major release was on September 7, when a peak ${ }^{133} \mathrm{Xe}$ activity of $4.3 \mu \mathrm{Ci} / \mathrm{mL}(159.1 \mathrm{kBq} / \mathrm{mL})$ was found in a grab sample of cover gas. Analysis of xenon-tag samples taken on the same day identified subassembly X181E (11.3 at. $\%$ peak burnup) as the source of the fission-gas release. Table IX summarizes the results of the xenon-tag analysis. Postirradiation examination identified element $73 \mathrm{E}$ as the breached element.

The reactor reached $62.5 \mathrm{MWt}$ for run 90D on September 8. The absence of very high activities of shorthalf-life fission gases confirmed subassembly $\mathrm{X} 181 \mathrm{E}$ as the source of the major fission-gas release during run 90C. However, the short-half-life fission-gas activities were still more than 20 times background, which indicated the presence of a slow leaker. Subassembly X181E, in the storage basket, also appeared to continue to release its aged plenum gas. The combination of the aged fission gas from subassembly $\mathrm{X} 181 \mathrm{E}$ and the fresh fission gas from the new slow leaker increased the ${ }^{133} \mathrm{Xe}$ activity level to a peak of $3.8 \mu \mathrm{Ci} / \mathrm{mL}(140.6 \mathrm{kBq} /$ $\mathrm{mL}$ ) on September 11. Subassembly X181E was removed to the HFEF on September 19. However, the high cover-gas activities persisted. On October 1, before the reactor shutdown for the end of run $90 \mathrm{D}$, the ${ }^{133} \mathrm{Xe}$ activity reached a peak of $950 \mathrm{nCi} / \mathrm{mL}(35.2 \mathrm{kBq} / \mathrm{mL})$. 
TABIE IX. Results of Xenon-tag Analysis on Septemiber 7, 1977

\begin{tabular}{lcc}
\hline & $\begin{array}{c}\text { Determined } \\
\text { from } \\
\text { Cover-gas } \\
\text { Sample }\end{array}$ & $\begin{array}{c}\text { Predicted for X181E at } \\
\text { Peak Burnup of 11.3 at. \% }\end{array}$ \\
Xenon volume, $m \mathrm{~L}$ & 20 & \\
Tag volume, mL & 0.2 & 136 \\
FG/ TG ratiog & 115 & 139 \\
Volume of gas in \\
element plenum, mL
\end{tabular}

${ }^{a}$ Ratio of total volume of stable fission gas (FG) to volume of tag gas (TG) as loaded.

Table $X$ summarizes the analyses of xenon-tag samples taken in September. The data indicated that oxide subassemoly X203D (11.9 at. \% peak burnup) was the source of the slow fission-gas release. The subassembly was moved to the storage basket at the end of the run, on October 1, as a suspected leaker.

TABLE X. Results of Xenon-tag Analyses in September 1977

\begin{tabular}{|c|c|c|c|c|c|}
\hline & \multicolumn{4}{|c|}{ Determined from Cover-gas Sample } & \multirow{3}{*}{$\begin{array}{l}\text { Predicted for X203D at } \\
\text { Peak Burnup of } 11.9 \text { at. } \%\end{array}$} \\
\hline & \multicolumn{4}{|c|}{ Sampling Date (September 1977) } & \\
\hline & 7 & 9 & 27 & 29 & \\
\hline Xenon volume, $\mathrm{mL}$ & 20 & 3.73 & 5.0 & 1.69 & $\cdot$ \\
\hline Tag volume, $\mathrm{mL}$ & 0.2 & 0.029 & 0.04 & 0.012 & $\cdot$ \\
\hline $\mathrm{FG} / \mathrm{TG}_{\mathrm{ratio}}^{\mathrm{a}}$ & 115 & 148 & 143 & 162 & 142 \\
\hline $\begin{array}{l}\text { Volume of gas in } \\
\text { element plenum, } \\
\mathrm{mL}\end{array}$ & 117 & $\cdot$ & - & - & - \\
\hline $\begin{array}{l}\text { Xenon isotopic } \\
\text { ratios }\end{array}$ & & & & & \\
\hline $131 / 134$ & 0.450 & 0.438 & 0.444 & 0.440 & $\cdot$ \\
\hline $134 / 133$ & 199.7 & 151.6 & 414 & 91.41 & - \\
\hline $129 / 128$ & 4.79 & 4.35 & 4.84 & 4.26 & 5.50 \\
\hline $129 / 124$ & 44.22 & 55.5 & 52.88 & 47.38 & 64.71 \\
\hline $128 / 124$ & 9.23 & 12.8 & 10.94 & 11.12 & 11.76 \\
\hline $126 / 124$ & 0.491 & 0.433 & 0.525 & 0.317 & 0.643 \\
\hline $129 / 126$ & 90.12 & 128.3 & 101.4 & 151 & 100.7 \\
\hline
\end{tabular}

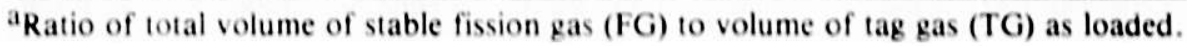


In run 91A, untagged oxide subassembly $\times 214$ was identified as a leaker. This raised the question of whether the observed tag releases in run 90D were a mixture of tag from subassembly X18iE and fission gas from subassembly $\times 214$. Examination of the tag ratios from the September tag samples showed that a mixture of fission gas and tag from X214 and X203D matched the measured ratios better than a mixture from $\times 214$ and $\times 181 \mathrm{E}$.

Subassembly X203D was reinserted during run 92A for confirmation. However, no fission-gas release from the subassembly was observed until run 94 . Visual examination after run 94 showed that one element in the subassembly had a large crack. Weight losses and gamma scanning for ${ }^{133} \mathrm{Xe}$ revealed another two possible breached elements.

\section{E. Subassemblies X214, X282, X294, X235A, and X291 (Runs 91 and 92 )}

During October-December 1977, there were fission-product releases from five subassemblies: X214, X282, X294, X235A, and X291. All the subassemblies except subassembly X214 were identified by their unique xenon tags. Subassemb!y $\times 214$ was untagged. It was identified as the source of fission-gas release by the absence of xenon tag and by its unique ${ }^{134} \mathrm{Xe} /{ }^{128} \mathrm{Xe}$ and ${ }^{131} \mathrm{Xe} /{ }^{134} \mathrm{Xe}$ ratios as an oxide subassembly with 21 at. $\%$ peak burnup.

Tables XI-XV summarize the results of xenon-tag analyses for the five subassemblies that released fission gas during this period.

I ABI.E XI. Results of Xenon-tag Analyses on October 12 and 14, 1977

\begin{tabular}{|c|c|c|c|}
\hline & \multicolumn{2}{|c|}{ Determined from Cover-gas Sample } & \multirow{3}{*}{$\begin{array}{l}\text { Predicted for } \times 214^{\mathrm{a}} \text { at } \\
\text { Peak Burnup of } 21 \text { at. }\end{array}$} \\
\hline & \multicolumn{2}{|c|}{ Sampling Date (October 1977) } & \\
\hline & 12 & 14 & \\
\hline Xenon volume, $\mathrm{mL}$ & 20.9 & 171 & . \\
\hline \multicolumn{4}{|l|}{ Xenon isotopic ratios } \\
\hline $131 / 134$ & 0.428 & 0.425 & $>0.4$ \\
\hline $134 / 133$ & 760.2 & 602 & $\cdot$ \\
\hline $129 / 128$ & 0.8 & 0.073 & . \\
\hline $134 / 128$ & 1525 & 1469 & $<2000$ \\
\hline
\end{tabular}

TABLE XII. Results of Xenon-tag Analysis on October 21, 1977

\begin{tabular}{lcc}
\hline & $\begin{array}{c}\text { Determined } \\
\text { from } \\
\text { Cover-gas } \\
\text { Sample }\end{array}$ & $\begin{array}{c}\text { Predicted for } \times 282^{\mathrm{a}} \text { at } \\
\text { Peak Burnup of } 5.7 \text { at. } \%\end{array}$ \\
\hline Xenon volume, $\mathrm{mL}$ & 3.9 & \\
Tag volume, $\mathrm{mL}$ & 0.11 & 22 \\
FG/TG ratio & 41 & 24 \\
Volume of gas in & & \\
element pienum, $\mathrm{mL}$ & 44 & $>0.437$ \\
Xenon isotopic ratios & & -8.56 \\
$131 / 134$ & 0.446 & 15.83 \\
$134 / 133$ & 1416 & 1.85 \\
$129 / 128$ & 7.18 & 0.427 \\
$129 / 124$ & 17.66 & 37.06 \\
$128 / 124$ & 2.46 & \\
$126 / 124$ & 0.444 & \\
$12 \% / 126$ & 39.83 & \\
\hline
\end{tabular}

a Helium-bonded nitride subassembly.

${ }^{b}$ Ratio of total volume of stable fission gas (FG) to volume of tag gas (TG) as loaded. 
TABLE XIII. Results of Xenon-tag Analysis on November 17, 1977

\begin{tabular}{lcc}
\hline & $\begin{array}{c}\text { Determined } \\
\text { from } \\
\text { Cover-gas } \\
\text { Sample }\end{array}$ & $\begin{array}{c}\text { Predicted for X294 at } \\
\text { Peak Burnup of } 3.5 \text { at. \% }\end{array}$ \\
\hline Xenon volume, $\mathrm{mL}$ & 4.98 & - \\
Tag volume, $\mathrm{mL}$ & 0.33 & - \\
FG/TG ratiob & 17 & 15 \\
Volume of gas in & & 16 \\
element plenum, $\mathrm{mL}$ & 18 & \\
Xenon isotopic ratios & & 2.440 \\
$131 / 134$ & 0.468 & - \\
$134 / 133$ & 410.5 & 9.39 \\
$129 / 128$ & 8.77 & 19.72 \\
$129 / 124$ & 20.66 & 2.10 \\
$128 / 124$ & 2.35 & 0.427 \\
$126 / 124$ & 0.451 & 46.21 \\
$129 / 126$ & 45.84 & \\
\hline
\end{tabular}

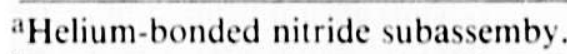

${ }^{b}$ Ratio of total volume of stable fission gas (FG) to volume of tag gas (TG) as loaded.

TABLE XIV. Results of Xenon-tag Analysis on December 14, 1977

\begin{tabular}{lcc}
\hline & $\begin{array}{c}\text { Determined } \\
\text { from } \\
\text { Cover-gas } \\
\text { Sampic }\end{array}$ & $\begin{array}{c}\text { Predicted for X235 } \mathrm{A}^{\mathrm{a}} \text { at } \\
\text { Peak Burnup of } 9.2 \text { at. \% }\end{array}$ \\
\hline Xenon volume, $\mathrm{mL}$ & 6.02 & - \\
Tag volume, $\mathrm{mL}$ & 0.14 & - \\
FG/TG ratio & 49 & $52-76$ \\
Volume of gas in & & \\
element plenum, mL & $48-69$ & 74 \\
Xenon isotopic ratios & & \\
$131 / 134$ & 0.426 & 5.429 \\
$134 / 133$ & 1490 & - \\
$129 / 128$ & 2.27 & 1.80 \\
$129 / 124$ & 17.22 & 13.94 \\
$128 / 124$ & 7.6 & 7.76 \\
$126 / 124$ & 0.487 & 0.461 \\
$129 / 126$ & 35.37 & 30.24 \\
\hline
\end{tabular}

aMark-II-fuel subassembly.

${ }^{b}$ Ratio of total volume of stable fission gas (FG) to volume of tag gas (TG) as loaded. 
TABLE XV. Results of Xenon-tag Analysis on December 22, 1977

\begin{tabular}{lcc}
\hline & $\begin{array}{c}\text { Determined } \\
\text { from } \\
\text { Cover-gas } \\
\text { Se nple }\end{array}$ & $\begin{array}{c}\text { Predicted for X291 a at } \\
\text { Peak Burnup of } 4.6 \text { at. } \%\end{array}$ \\
\hline Xenon volume, $\mathrm{mL}$ & 0.82 & - \\
Tag volume, $\mathrm{mL}$ & 0.035 & - \\
FG/TG ratio & 20 \\
Volume of gas in & 27 & 21 \\
element plenum, mL & 29 & \\
Xenon isotopic ratios & & 20.438 \\
$131 / 134$ & 0.451 & - \\
$134 / 133$ & 557.8 & 9.94 \\
$129 / 128$ & 7.14 & 31.12 \\
$129 / 124$ & 30.69 & 3.13 \\
$128 / 124$ & 4.33 & 0.452 \\
$126 / 124$ & 0.387 & 68.85 \\
$129 / 126$ & 79.8 & \\
\hline
\end{tabular}

${ }^{a}$ Helium-bonded carbide subassembly.

${ }^{b}$ Ratio of total volume of stable fission gas (FG) to volume of tag gas (TG) as loaded.

Except for the sodium-bonded carbide subassembly $\times 291$, at a peak burnup of 4.6 at. $\%$, none of the fission-product releases produced detectable delayed-neutren signals. The delayed-neutron signal produced 'y the breach in X291 was 20 counts/s above background. Because the subassembly was emitting delayed neutrons and was adjacent to two control rods, the flux-tilting test could be used to confirm X291 as the fission-product source. The other three fission-product sources identified by their unique xenon-tag compositions daring runs 91 and 92 were two helium-bonded nitride subassemblies (X282 and X294) and sodiumbonded Mark-II subassembly X235A, which were at peak burnups of 5.7, 3.5, and 9.2 at. $\%$, respectively.

Table XVI summarizes the breached elements identiried during postirradiation examination.

TABLE XVI. Summary of Elements Breached in Runs 91 and 92

\begin{tabular}{|c|c|c|c|}
\hline $\begin{array}{c}\text { Subassembly } \\
\text { Number }\end{array}$ & $\begin{array}{l}\text { Numbers of } \\
\text { Breached Elements }\end{array}$ & Breach Location & Observations \\
\hline$\times 214$ & $29 \mathrm{C}$ and $014 \mathrm{~S}$ & Unknown & $\begin{array}{l}\text { Weight loss; } \\
{ }^{133} \text { Xe activity }\end{array}$ \\
\hline$\times 282$ & 7 & Fuel column & Visible crack \\
\hline X294 & 21 & Fuel column & $\begin{array}{l}\text { Visible crack or } \\
\text { scratch }\end{array}$ \\
\hline $\mathrm{X} 235 \mathrm{~A}$ & $33,34,43$, and 55 & Dimple area & Weight loss \\
\hline X291 & 17 & Fuel column & $\begin{array}{l}\text { Visible crack; } \\
\text { weight gain of } \\
1.07 \mathrm{~g}\end{array}$ \\
\hline
\end{tabular}




\section{F. Subassemblies X206A, X154A, X271A, X342, X203D, and C-2884A (Runs 93 and 94)}

Intermittent releases of long-lived fission-product gases were observed during the last part of run 92 and persisted through run 93. This period of operation covered January-March 1978. Six xenon-tag samples were taken from the cover gas during this period, but none of the analyses positively identified the source of release. Table XVII summarizes the results of the analyses, and Fig. 2 maps the tag ratios of the samples. Some of the sample compositions were similar to that of the xenon tag in subassembly X206A; others could have been a mixture of that tag with the tag from subassembly X154A. Both subassemblies contaned mixedoxide fuel elements that had a low enrichment of ${ }^{235} \mathrm{U}$ and fissioned predominantly in the plutonium. A high measured ${ }^{131} \mathrm{Xe} /{ }^{134} \mathrm{Xe}$ ratio in the cover gas is indicative of a release from elements of this type. Thus, an element in either (or both) subassemblies could have been the source of release. The volume of xenon tag released at any one time was too small $(0.028 \mathrm{~mL}$ or less) for further identification, and the reactor was kept running until it was shut down on March 23 for scheduled annual maintenance.

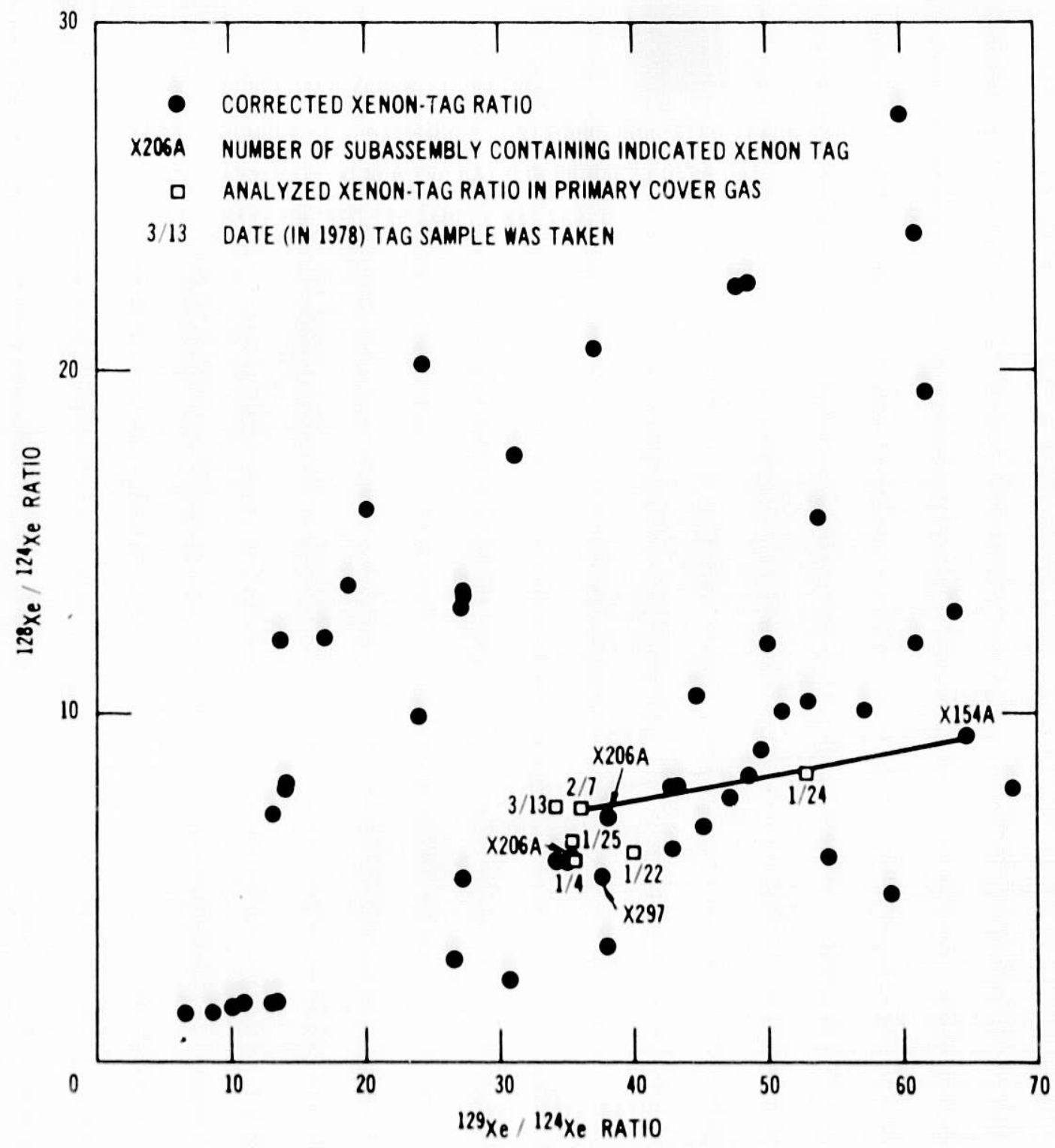

Fig. 2. Two-dimensional Xenon-tag Map for Runs 92 and 93 
TABLE XVII. Results of Xenon-tag Analyses in January-March 1978

\begin{tabular}{|c|c|c|c|c|c|c|c|}
\hline & \multicolumn{6}{|c|}{ Determined from Cover-gas Sample } & \multirow{3}{*}{$\begin{array}{l}\text { Predicted } \\
\text { for } \times 206 \mathrm{~A} \\
\text { at Peak Burnup } \\
\text { of } 7.6 \text { at. } \%\end{array}$} \\
\hline & \multicolumn{6}{|c|}{ Sampling Date (1978) } & \\
\hline & $1 / 4$ & $1 / 22$ & $1 / 24$ & $1 / 25$ & $2 / 7$ & $3 / 13$ & \\
\hline Xenon volume, $\mathrm{mL}$. & 2.41 & 1.95 & 2.68 & 2.41 & 1.78 & 1.23 & . \\
\hline Tag volume, $\mathrm{mL}$ & 0.028 & 0.017 & 0.025 & 0.021 & 0.013 & 0.014 & - \\
\hline $\mathrm{FG} / \mathrm{TG}_{\text {ratio }}^{\mathrm{a}}$ & 99 & 132 & 123 & 132 & 157 & 101 & 108 \\
\hline $\begin{array}{l}\text { Volume of gas in } \\
\text { element plenum, } \mathrm{mL} \\
\text { Xenon isotopic ratios }\end{array}$ & $114-137$ & $152-182$ & $141-170$ & 152.182 & 181.217 & $161-139$ & 129 \\
\hline $131 / 134$ & 0.432 & 0.503 & 0.471 & 0.463 & 0.463 & 0.463 & \\
\hline $134 / 633$ & $9: 3$ & 13.116 & 255 & 144 & 923 & 993 & - \\
\hline $129 / 128$ & 6.190 & 6.722 & 6.440 & 5.640 & 4.923 & 4. 662 & 5.34 \\
\hline $129 /$ & 35.55 & 40.03 & 52.57 & 35.38 & 36.05 & 34.10 & 38.10 \\
\hline $128 / 124$ & 5.742 & 5.955 & 8.245 & 6.274 & 7.323 & 7.314 & 7.14 \\
\hline $126 / 124$ & 0.443 & 0.582 & 0490 & 0.452 & 0.306 & 0.382 & 0.536 \\
\hline $129 / 126$ & 77.86 & 68.77 & 107 & 78.27 & 1176 & 89.18 & 71.11 \\
\hline $\begin{array}{l}{ }^{0}{ }^{129} \mathrm{Xe}_{\mathrm{in}} \\
\text { cover gas }{ }^{\mathrm{b}}\end{array}$ & 86.09 & 87.05 & 86.44 & 84.94 & 83.12 & 82.34 & 84.21 \\
\hline
\end{tabular}

Run 94 began on April 14. The activities of short-lived fission gases were about 20 times normal background because of the presence of the fission-product-source test (subassembly X288A), which had been reinserted to calibrate the upgraded FERD. At about 1300 on April 15, there was a large increase in all fissiongas activities. A cover-gas sample indicated release of a xenon tag. Table XVIil compares the tag ratios for this sample with those for the primary suspects.

TABLE XVIII. Summary of Primary Suspects for April 15 and 16, 1978, Fission-product Releases

\begin{tabular}{|c|c|c|c|c|c|c|c|}
\hline & $\begin{array}{c}\text { Determined } \\
\text { from } \\
4 / 16 / 78 \\
\text { Cover-gas } \\
\text { Sample }\end{array}$ & X154A & \multicolumn{2}{|c|}{ X203D } & \multirow{2}{*}{$\begin{array}{r}\mathrm{X} 227 \mathrm{~A} \\
10.5\end{array}$} & \multirow{2}{*}{$\begin{array}{l}94.3 \% \times 154 A \\
5.7 \% \times 206 \mathrm{~A}^{\mathrm{a}}\end{array}$} & \multirow{2}{*}{$\begin{array}{r}51 \% \times 342 \\
49 \% \times 203 D^{b} \\
\end{array}$} \\
\hline Burnup, at. $\%$ & - & 13.1 & 10.7 & 14.2 & & & \\
\hline Tag number & - & $5 \times 4604$ & $3 \mathrm{X}$ & 5209 & $3 \times 5209$ & - & - \\
\hline Xenon volume, $\mathrm{mL}$. & 38.8 & & - & - & - & - & - \\
\hline Tag volume, $\mathrm{mL}$ & 0.65 & - & - & - & - & $\cdot$ & - \\
\hline $\mathrm{FG} / \mathrm{TG}_{\mathrm{ratio}}^{\mathrm{C}}$ & 69 & $60-123^{d}$ & 80 & 107 & 106 & $50-99^{d}$ & $58-64$ \\
\hline \multicolumn{8}{|l|}{ Xenon isotopic ratios } \\
\hline $131 / 134$ & 0.455 & $>0.440$ & $<0.447$ & $<0.438$ & $<0.448$ & $>0.441$ & $<0.444$ \\
\hline $129 / 124$ & 62.53 & 65.37 & 62.39 & 66.10 & 61.93 & 62.50 & 62.70 \\
\hline $128 / 129$ & 9.21 & 9.68 & 12.15 & 14.43 & 12.79 & 9.48 & 9.11 \\
\hline $126 / 124$ & 0.588 & 0.602 & 0.620 & 0.656 & 0.615 & 0.586 & 0.572 \\
\hline $129 / 126$ & 106 & 109 & $10 !$ & 101 & 101 & 107 & 110 \\
\hline Match factor ${ }^{\mathrm{e}}$ & - & 3.12 & 2.96 & 6.20 & 3.63 & 0.27 & $0.21^{f}$ \\
\hline $\begin{array}{l}\text { Equally weighted } \\
\text { match factorg }\end{array}$ & . & 4.91 & 27.54 & 41.53 & 34.00 & 1.49 & $2.09^{\mathrm{h}} \quad 2.66^{\mathrm{f}}$ \\
\hline
\end{tabular}

a Result of MIXTAG-code analysis.

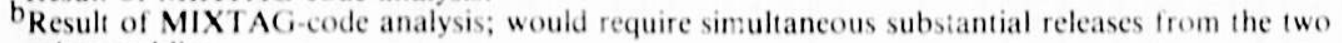
subassemblies.

Ratio of total volume of stable fission gas (FG) to volume of tag gas (T G) as loaded.

$\mathrm{d}_{\text {Large uncertainty is caused by use of a gas-release model for the prediction that is not designed }}$ for low-enrichment fuel pins.

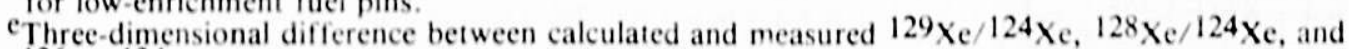
$126 \mathrm{Xe} / 124 \mathrm{Xe}$ ratios; equals zero for perfect match.

f Subassembly-X203D elements at 14.2 at. \% burnup.

gFour-dimensional difference between calculated and measured $124 \mathrm{Xe}, 126 \mathrm{Xe}, 128 \mathrm{Xe}$, and

$129 \mathrm{Xe}$ mole percentages on equally weighted basis.

${ }^{h}$ Subassembly-X203D elements at 10.7 at. \% burnup. 
Overall, subassembly $\mathrm{X} 154 \mathrm{~A}$ was the most likely source of the release. The measured ${ }^{131} \mathrm{Xe} /{ }^{134} \mathrm{Xe}$ ratio of 0.455 indicated a predominantly plutonium-fissioning source a finding consistent with the low ${ }^{235} \mathrm{U}$ enrichment in X154A. Although the match factors (numerically zero for a perfect match) for all three primary suspects (X154A, X203D, and X227A) were similar, the equally weighted match factors (based on mole percentages of ${ }^{124} \mathrm{Xe},{ }^{126} \mathrm{Xe},{ }^{128} \mathrm{Xe}$, and ${ }^{129} \mathrm{Xe}$ that have been equally weighted by statistics) strongly pointed to subassembly X154A. Nevertheless, to ensure a clean core for the source-test calibration, all three subassemblies were removed to the storage basket. It was hoped that isolatior iesting in the FUM would uniquely identify the source subassembly

Further analysis of the xenon-tag data for April 15 and 16 showed that the match factor for subassembly X154A could be reduced substantially (from 3.12 to 0.27 ) by accounting for contamination from subassembly X206A, which appeared to have leaked during runs 92 and 93 . The match factor was not reduced for subassemblies X203D and X227A when contamination from subassembly X206A was assumed for each. The reduction in match factor was taken as additional evidence that X154A was primarily responsible for the release on April 15 and 16. A total fission-gas volume of $98 \mathrm{~mL}$ was obtained from subassembly X154A; of this, about $27 \mathrm{~mL}$ was obtained after the subassembly had been removed to the reactor storage basket. These values indicate that probably more than one element had breached.

Another possible cause was the simultaneous or near-simultaneous release from subassemblies X342 and $\mathrm{X} 203 \mathrm{D}$. This possibility was later discounted because (1) simultaneous major releases have very low probability, (2) the expected ${ }^{131} \mathrm{Xe} /{ }^{134} \mathrm{Xe}$ ratio of $<0.444$ was too small compared to the measured value of 0.455 , and (3) sodium analysis later showed a large ${ }^{131} \mathrm{I}$ release $[4.405 \mathrm{nCi}(-163 \mathrm{~V} \mathrm{~Bq})$ per gram of sodium $]$ between April 20 and 26 without accompanying ${ }^{137} \mathrm{Cs}$ release, a behavior typical of that for a release from a lowburnup fuel element. The latter data indicated that the release from subassembly X 342 did not occur before April 20

The reactor was restarted at 2340 on April 16. As it reached full power at 1055 on April 17, increased fission-gas activity in the cover gas indicated that there was an active source in the core. A xenon-tag sample was taken between 1400 and 1530 on April 17. Analysis of the sample indicated a substantial shift in composition from that of the sample taken on April 16 and toward that for subassembly X271A. (See Fig. 3 and Table XIX.) When the contamination from X154A, now in the storage basket, was assumed considerable $(55 \%)$, the match factor for subassembly X271A was 0.07 . The total fission-gas release was about $28 \mathrm{~mL}$.

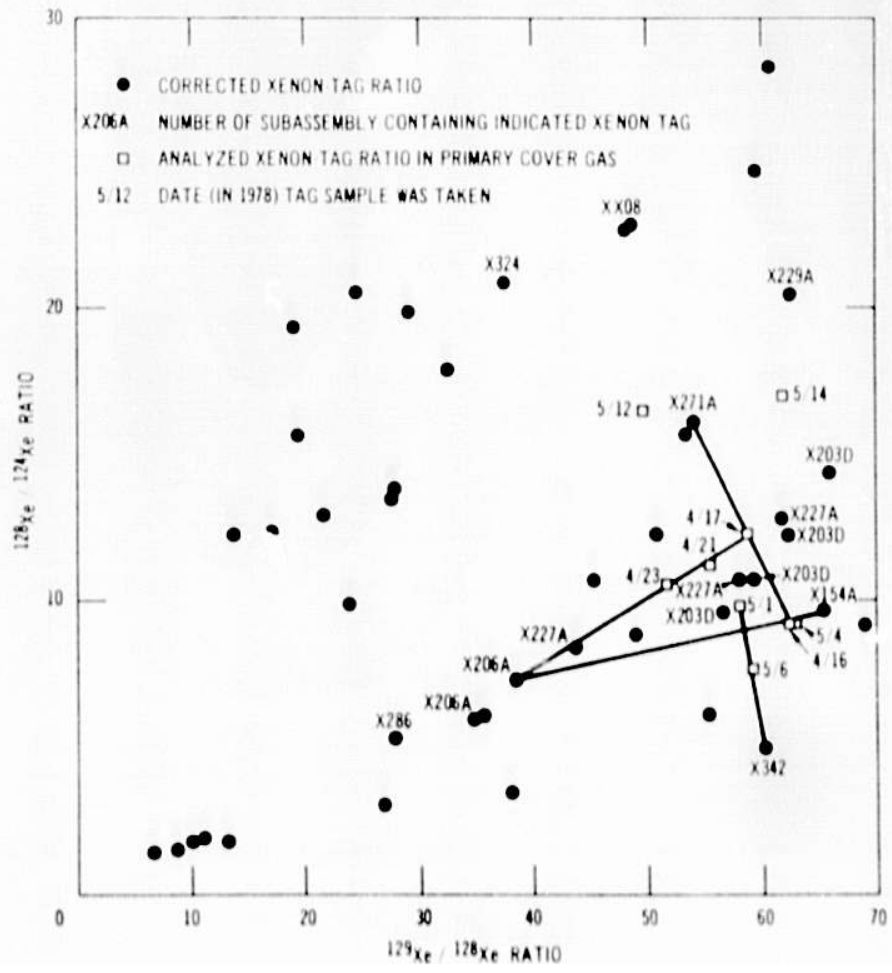

Fig. 3

Two-dimensional Xenon-tag Map for Run 94 
TABLE XIX. Results of Xenon-tag Analyses in March-May 1978

\begin{tabular}{|c|c|c|c|c|c|c|c|c|c|c|c|c|c|}
\hline \multicolumn{14}{|c|}{ Sampling Date (1978) } \\
\hline & $3 / 13$ & $4 / 16$ & $4 / 17$ & $4 / 21$ & $4 / 23$ & $4 / 23^{a}$ & $4 / 26$ & $5 / 1$ & $5 / 4$ & $5 / 6$ & $5 / 9$ & $5 / 12$ & $5 / 14$ \\
\hline FERD signal & No & No & No & No & No & Yes & Yes & No & No & No & No & No & Yes \\
\hline $\begin{array}{l}\text { Xenon in cover } \\
\text { gas, } \mathrm{mL}\end{array}$ & 1.23 & 38.8 & 20.2 & 3 & 3.66 & 3.3 & 1.37 & 1.89 & 6.78 & 1.48 & 9.84 & 9.66 & 91.9 \\
\hline $\begin{array}{l}\text { Tag in cover } \\
\text { gas, } \mathrm{mL}\end{array}$ & 0.014 & 0.65 & 0.19 & 0.03 & 0.032 & 0.054 & 0.012 & 0.017 & 0.038 & 0.010 & 0.011 & 0.013 & 0.59 \\
\hline FG/TG ratio b & 101 & 69 & 122 & 115 & 131 & 70 & $13 \mathrm{i}$ & 128 & 205 & 170 & 1028 & 854 & 179 \\
\hline $\begin{array}{l}\text { Volume of gas } \\
\text { in element } \\
\text { plenum, mL }\end{array}$ & $93-230$ & $69-138$ & $122-244$ & $115-230$ & $131-262$ & $70-140$ & $131-262$ & $128-256$ & $205-410$ & $190-340$ & $1028-2056$ & $854-1708$ & $179-358$ \\
\hline \multicolumn{14}{|l|}{$\begin{array}{l}\text { Xenon isotopic } \\
\text { ratios in cover } \\
\text { gas }\end{array}$} \\
\hline $131 / 134$ & 0.463 & 0.455 & 0.450 & 0.444 & 0.437 & 0.442 & 0.412 & 0.436 & 0.424 & 0.428 & 0.418 & 0.416 & 0.443 \\
\hline $134 / 133$ & 993 & 3164 & 1693 & 162 & 85.47 & 67.66 & 18.24 & 433 & 801 & 571 & 783 & 674 & 3858 \\
\hline $129 / 128$ & 4.66 & 6.79 & 4.76 & 4.98 & 4.81 & 6.81 & 5.97 & 5.91 & 6.758 & .681 & 2.71 & 3.02 & 3.64 \\
\hline $129 / 124$ & 34.10 & 62.53 & 58.73 & 55.5 & 51.65 & c & c & 58.13 & 63.07 & 59.26 & $\mathrm{c}$ & 49.75 & $6 ! .81$ \\
\hline $128 / 124$ & 7.31 & 9.21 & 12.33 & 11.15 & 10.59 & c & $\mathrm{c}$ & 9.83 & 9.333 & 7.714 & $\mathrm{c}$ & 16.50 & 17.00 \\
\hline $126 / 124$ & 0.382 & 0.588 & 0.521 & 0.611 & 0.549 & $c$ & c & 0.362 & 0.407 & 0.400 & c & 0.500 & 0.677 \\
\hline $129 / 126$ & 93.3 & 106 & 113 & 90.8 & 94.1 & $\mathrm{c}$ & c & 161 & 155 & 148 & c & 99.50 & 91.23 \\
\hline
\end{tabular}

May have been contaminated with $\mathrm{CO}_{2}$.

${ }^{b}$ Ratio of total volume of stable fission gas (FG) to volume of tag gas (TG) as loaded.

cXenon-124 and 126 Xe vic not measurable. 
After the initial release, the short-lived ${ }^{138} \mathrm{Xe}$ activity dropped back to its expected level with the source test in the core; all other fission-gas activities, however, leveled off above expected values. The reactor was kept running to obtain further diagnostic information.

During a flux-tilting test on April 21 to determine the response of the upgraded FERD system, a bubble of fission gas was released from the core. Tag-sample analysis indicated that the ${ }^{134} \mathrm{Xe} /{ }^{133} \mathrm{Xe}$ ratio had changed from the previous value of 1693 to 162; it was therefore apparent that the bubble contained fresh fission gas. Xenon-tag analysis showed that the tag composition has shifted toward that for subassembly X206A. (See Fig. 3.) Two additional tag samples were taken on April 23 after additional fission gas was released during other flux-tilting tests. The low ${ }^{134} \mathrm{Xe} /{ }^{133} \mathrm{Xe}$ ratios of about 85 and 68 in the samples indicated a continued release of a very fresh fission gas. The shift in the composition of the $0.032 \mathrm{~mL}$ of xenon tag in the cover gas toward that for subassembly X206A (see Fig. 3) was probably caused by a release of about $5 \mathrm{~mL}$ of xenon from that subassembly.

To induce enough release of xenon tag for accurate mass spectrometry, the reactor power was reduced rapidly to $30 \mathrm{MWt}$ at 0630 on April 26 and then raised to $62.5 \mathrm{MWt}$. The cover-gas activities increased appreciably during the power increase. In addition, the delayed-neutron monitor FERD had already recorded at $56 \mathrm{MWt}$ the expected signal from the source test at $62.5 \mathrm{MWt}$. The reactor was scrammed at 0730 when the FERD signal finally reached the shutdown limit. Analysis of a xenon-tag sample taken after shutdown indicated that the released fission gas was very fresh $\left({ }^{134} \mathrm{Xe} /{ }^{133} \mathrm{Xe}=18.24\right)$.

Although the amount of xenon tag accompanying the release was insufficient to allow measurement of the mole percent of ${ }^{124} \mathrm{Xe}$ and ${ }^{126} \mathrm{Xe}$ in the cover gas, the increase of the ${ }^{129} \mathrm{Xe} /{ }^{128} \mathrm{Xe}$ ratio from about 4.9 to the range of 5.97-6.81 indicated that the ${ }^{129} \mathrm{Xe} /{ }^{128} \mathrm{Xe}$ ratio for the new leaker had to be $\geq 5.97$. The probable suspects were subassemblies X276A, XX08, X341, and X342. Table XX gives the pertinent information about these suspects. Since there was no obvious indication that rapid sodium release accompanied the FERD signal, subassemblies X276A and XX08, containing sodium-bonded fuel elements, were dropped as suspects. Of the two remaining suspects, subassembly $\mathrm{X} 342$ was the more likely leaker, because of its higher burnup and lower oxygen/metal $(\mathrm{O} / \mathrm{M})$ ratio.

TABLE XX. Suspect Subassemblies with ${ }^{129}$ Xe $/{ }^{128}$ Xe Tag Ratios Greater than 5.97

\begin{tabular}{cccccc}
\hline $\begin{array}{c}\text { Subassembly } \\
\text { No. }\end{array}$ & $\begin{array}{c}\text { Fuel } \\
\text { Type }\end{array}$ & $\begin{array}{c}\text { Bond } \\
\text { Type }\end{array}$ & $\begin{array}{c}\text { Maximum } \\
\text { Burnup, at. } \%\end{array}$ & $\begin{array}{c}\text { Peak } \\
\text { Linear } \\
\text { Power, } \mathrm{kW} / \mathrm{ft}^{\mathrm{a}}\end{array}$ & $\begin{array}{c}\text { Initial } \\
\text { O/nimum }\end{array}$ \\
\hline X276A & Carbide & Sodium & 10.2 & 23.8 & 0 \\
XX08 & Metal & Sodium & 3.3 & 7.2 & 0 \\
X341 & Oxide & Helium & 1.4 & 11.7 & 1.93 \\
X342 & Oxide & Helium & 1.7 & 12.0 & 1.91 \\
\hline
\end{tabular}

${ }^{\mathrm{a} C o n v e r s i o n}$ factor: $1 \mathrm{~kW} / \mathrm{ft}=3.281 \mathrm{~kW} / \mathrm{m}$.

There appeared to be at least three active sources in the reactor core. The most likely suspect subassemblies were X206A, X271A, and X342. These three were removed along with subassembly X229A, which contained oxide fuel at 13.9 at. $\%$ and was taken out of the reactor grid because of its high failure probability. The fission-product-source experiment (X288A) was also removed. The reactor was restarted for run $94 \mathrm{C}$ and reached full power at 1401 on April 28. The absence of abnormal cover-gas activities indicated that all sources of activity had been removed. 
Subassemblies X203D and X227A were returned to the core for run 94D. During startup, above-normal activities were observed for short-lived isotopes at about $20 \mathrm{MWt}$. Shortly after full power was reached, the fission-gas activity began increasing rapidly, and an increase was also seen in the FERD signal. By 0552 on May 14, the FERD signal had increased to near the alarm limit. Run 94D was terminated by an anticipatory shutdown. Analysis of a tag sample taken on May 14 indicated that there were about $92 \mathrm{~mL}$ of fission gas and $0.59 \mathrm{~mL}$ of tag gas in the cover gas. With subassembly X229A in the storage basket, the most likely suspect was subassembly X203D rather than X227A, which had the same tag, but contained elements with lower burnup. An increase of cover-gas activity obtained while subassembly X203D was raised above the core further confirmed that this subassembly was responsible for the release on May 13 and 14. Only that subassembly was removed to the storage basket.

Because of the large difference between the tag compositions in the April 16 and May 14 samples (see Table XIX and Fig. 3), the release of fission gas from subassembly X203D during startup did not compromise the previous conclusion that subassembly X154A had been responsible for the fission-gas release on April 16. The total fission-gas release for May 13-15 was calculated to be over $200 \mathrm{~mL}$; the magnitude of the release indicated that there was probably more than one breached element in subassembly X203D.

Subassembly X229 was returned to the core for run 94E. At full power, the short-lived activity remained at or below background level, so the core apparently was free of leakers. (By process of elimination, a Mark-II subassembly, C-2884A, with a burnup of 8 at. $\%$, was later determined to be responsible for a low background release of long-lived activity at this time.)

Subassembly X342 had been initially confirmed as a leaker by the activity and xenon tag it released diring the "hold-and-blow" stage of the FUM isolation test. It was finally confirmed as a leaker by reinseriing it into the core for run $94 \mathrm{H}$. The reactor was manually scrammed at about $30 \mathrm{MWt}$ when the delayed-neutron signal resulting from the leaking $\mathrm{X} 342$ exceeded the normal startup limit.

There also had been some indication of ${ }^{133} \mathrm{Xe}$ release from subassembly X206A during the hold-and-blow stage of its FUM isolation test. However, the FUM tests for subassemblies X271A and X154A were negative. Subassembly X271A was later returned to the core for further irradiation, but no confirmatory fissionproduct release was observed. Whether there was a cladding breach in subassembly X271A that later resealed can be determined only by postirradiation examination.

Table XXI summarizes the breached elements identified by postirradiation examination. Such examinations have not been performed on subassemblies X206A, X154A, and X271A.

TABLE XXI. Summary of Elements Breached in Runs 93 and 94

\begin{tabular}{cccl}
\hline $\begin{array}{c}\text { Subassembly } \\
\text { Number }\end{array}$ & $\begin{array}{c}\text { Numbers of } \\
\text { Breached Elements }\end{array}$ & \multicolumn{1}{c}{$\begin{array}{c}\text { Breach } \\
\text { Location }\end{array}$} & \multicolumn{1}{c}{ Observations } \\
\hline X342 & D1 & $\begin{array}{l}\text { Just above midplane } \\
\text { of fuel column }\end{array}$ & Visible crack \\
X203D & Fuel-column region & $\begin{array}{l}\text { Visible crack } \\
\text { 7A and 64E }\end{array}$ & $\begin{array}{l}\text { Suspects; 1 g or more } \\
\text { weight loss; low } \\
\text { 133 Xe activity }\end{array}$ \\
C-2884A & Upper weld & $\begin{array}{l}\text { Examination has not } \\
\text { been completed; breach } \\
\text { site was located by } \\
\text { pressurization }\end{array}$ \\
\hline
\end{tabular}




\section{SUMMARY AND CONCLUSIONS}

During this reporting period, 18 subassemblies were suspected to contain one or more breached elements. Postirradiation examination of 15 of these subassemblies confirmed the presence of at least one breached element in each. The 15 subassemblies included six containing reference oxide fuel, one containing advanced oxide fuel, four metal fuel, two helium-bonded nitride fuel, one helium-bonded carbide fuel, and one sodiumbonded carbide fuel. Two of the three suspected leakers contained oxide fuel, and one contained metal fuel.

Subassembly C-2884A contained the first confirmed breach of a metal-fuel element manufactured by Atomics International (AI). Failure of the top weld in the subassembly suggested that AI metal fuel may breach differently than ANL-produced metal fuel. Subassembly X246A contained the first breach of sodiumbondes and shrouded carbide fuel. The first element breach in a grid cupported oxide subassembly was in $\mathrm{X} 154 \mathrm{~A}$ (if the breach is confirmed in postirradiation examiitation)

When the fission-gas release is isolated and substantial, identification by xenon tag is quick and unique. If the release is slow (as has been the case for most carbide fuel, nitride fuel, advanced oxide fuel, and metal fus: . with top weld failure), there is a large uncertainty in xenon-tag analysis. A prolonged search for a leaker with a slow fission-gas release increases the probability of multiple breaches from a single subassembly or several subassemblies.

Detecting the presence of multiple tags (usually from different subassemblies) in the cover gas was not difficult with frequent sampling to detect shifts of xenon-tag compositions. But to uniquely identify all the xenon-tag sources required sophisticated analysis. Sorting out multiple tags is very difficult-especially for EBR-II, because xenon-tag compositions used in EBR-II are not designed for identification of multiple tag releases. The computer rogram MIXTAG has been helpful on many occasions. On-line mass-spectrometric analyses of cover gas (when available) will also help. But the confusion with mixed tags cannot be eliminated.

Detecting multiple breaches from elements with the same tag is also difficult. Postirradiation examination showed that three and possibly four subassemblies contained multiple breaches. Although during the leaker search there was suspicion of multiple breaches in the same subassembly, there was not enough concrete evidence to prove the case.

More multiple-tag mixing is expected to be encountered in the future in EBR-II because:

1. Run-beyond-cladding-breach ( $\mathrm{RBCB}$ ) tests will be in operation.

2. Many subassemblies near end of life will be in the core.

3. Many advanced-fuel subassemblies that tend to have a slow rate of fission-gas release will be in the core.

4. For ease in identifying a breached element during postirradiation examination, experimenters have requested irradiation of the subassembly containing the element until sufficient plenum gas has been released.

5. The new cover-gas cleanup system (CGCS) allows RBCB operation until sufficient tag data are collected instead of taking the penalty of shutting down the reactor to remove some suspects.

During April 16-May 15 of this reporting period, possibly six subassemblies released fission gas. As discussed in the previous paragraph, such frequency of fission-gas releases can be expected in the future. Uncontaminated tag samples and a clean core can become rare. To confirm that the subassembly has breached, the lift-and-hold and FUM isolation tests, which proved to be valuable during this reporting period, may become a standard operation.

Activity of ${ }^{137} \mathrm{Cs}$ in the primary sodium has been kept at a low level $[\sim 30-40 \mathrm{nCi} / \mathrm{g}(1.1-1.5 \mathrm{kBq} / \mathrm{g})]$ by the cesium trap, which preferentially adsorbs cesium on a reticulated-vitreous-carbon column. Primary-sodium activity has not impacted directly on plant availability. Downtime caused by identification of breached elements was near its lowest possible value. 


\section{REFERENCES}

1. R. R. Smith, D. W. Cissel, C. B. Doe, E. R. Ebersole, and F. S. Kirn, Locating and Identifying the Source of the May 24, 1967, Fission-product Release to EBR-II, ANL-7543 (Apr 1969).

2. R. R. Smith, E. R. Ebersole, R. M. Fryer, and P. B. Henault, Origin of Fission-product Releases in EBR-II, November 23, 1967, to May 6, 1968, ANL 7604 (Dec 1970).

3. R. M. Fryer, E. R. Ebersole, P. B. Henault, and R. R. Smith, Symptoms and Detection of a Fission-product Release from an EBR-II Fuel Element: Case 1. Defect above Fuel Elevation, ANL-7605 (Jan 1970).

4. R. R. Smith, C. B. Doe, and E. R. Ebersole, Exposed-fuel Calibration Study in EBR-II, Second Series, ANL-7558 (Jan 1970).

5. R. M. Fryer, R. R. Smith, E. R. Ebersole, and R. V. Strain, Symptoms and Detection of a Fissionproduct Release from an EBR-II Fuel Element: Case 2. Defect below Fuel Elevation, ANL-7676 (June 1970).

6. G. S. Brunson, R. M. Fryer, and R. V. Strain, Experimental Irradiations of Fuel Elements Having Known Cladding Defects in EBR-II, ANL-7782 (July 1971).

7. R. R. Smith, G. S. Brunson, E. R. Ebersole, R. M. Fryer, P. B. Henault, and J. F. Koenig, Fission-product Releases to the Primary System of EBR-II during 1971, ANL-7956 (Nov 1972).

8. T. D. Claar, G. S. Brunson, E. R. Ebersole, J. R. Honekamp, and D. L. Johnson, Fission-product Releases to the Primary System of EBR-II during 1972 and 1973, ANL-8128 (to be published).

9. B. Y. C. So, J. D. B. Lambert, D. L. Johnson, E. R. Ebersole, and G. S. Brunson, Fission-product Releases to the Primary System of EBR-II from January 1974 to March 1975, ANL-76-65 (Oct 1976).

10. B. Y. C. So, J. D. B. Lambert, F. S. Kirn, J. R. Armstrong, E. R. Ebersole, and M. T. Laug, Fission-product Releases to the Primary System of EBR-II from April 1975 to March 1977, ANL-79-26 (May 1979).

11. G. S. Brunson, On-line Noble Gas Fission Product Monitoring in EBR-II, Nucl. Technol. 10, 33 (Jan 1971).

12. G. S. Brunson, Monitoring Fission Gas in EBR-II by High Resolution Gamma Spectrometry, Nucl. Technol. 25, 553 (Mar 1975).

13. C. R. F. Smith and J. T. Holmes, Purity of EBR-II Sodium: 1967-1974, ANL-75-26 (Dec 1975).

14. N. J. Olson, C. M. Walter, and W. N. Beck, Statistical and Metallurgical Analysis of Experimental Mark-IA Driver Fuel Element Cladding Failures in the Experimental Breeder Reactor II, Nucl. Technol. 28, 134 (1976).

15. B. R. Seidel and R. E. Einziger, "In-reactor Cladding Breach of EBR-II Driver-fuel Elements," Proc. Int. Conf. on Radiation Effects in Breeder Reactor Structural Materials, Scottsdale, Ariz., June 1923, 1977, M. L. Bleiberg and J. W. Bennett, Eds., Metallurgical Soc. of AIME, N.Y., pp. 139-158 (1977).

16. G. L. Hofman, Application of Statistical Analysis to Cladding Failure in a Multiparameter Irradiation Program, Trans. Am. Nucl. Soc. 18, 125 (June 1974).

17. J. D. B. Lambert, B. Y. C. So, and M. T. Laug, Use of $\left({ }^{131} \mathrm{Xe} / 134 \mathrm{Xe}\right)$ Ratio to Distinguish Between Defective Uranium and Plutonium-bearing Elements in EBR-II, Trans. Am. Nucl. Soc. 23, 474 (1976).

18. T. D. Claar, G. O. Hayner, M. T. Laug, and R. W. Bono, Development and Use of Gamma Scanning to Determine Rates of Fission-gas Release from Nuclear Fuels, ANL-8116 (Oct 1974).

19. D. L. Johnson and G. L. Hofman, A Parametric Approach to the Release of Fission Gas from (U, $\mathrm{Pu}) \mathrm{O}_{2}$ Irradiated in EBR-II, Trans. Am. Nucl. Soc. 19, 138 (1974). 
20. G. L. Hofman and D. L. Johnson, Semiempirical Correlations for the Fission Gas Release from Fast Reactor Fuels, Trans. Am. Nucl. Soc. 21, 179 (1975).

21. B. Y. C. So, J. D. B. Lambert, E. R. Ebersole, and M. T. Laug, Change in Xenon Tag Composition with Exposure--EBR-II Experience, Trans. Am. Nucl. Soc. 23, 473 (1976).

22. 3. Y. C. So, J. D. B. Lambert, and E. R. Ebersole, Fractional Release of Xenon Tag and Fission Gas from Defective Elements in EBR-II, Trans. Am. Nucl. Soc. 23, 472 (1976).

23. R. V. Strain and J. D. B. Lambert, Results of $\mathrm{UO}_{2}$ Diagnostic Tests for Run Beyond Cladding Breach in EBR-II, ANL-78-99 (Feb 1979).

24. B. Y. C. So and G. W. Stauffer, MIXTAG-A Code to Identify a Second Xenon Tag in EBR-II Cover Gas in the Presence of a First Tag, Trans. Am. Nucl. Soc. 26, 522 (1977). 